\title{
13. MAJOR-ELEMENT CHEMISTRY OF BASALTIC GLASSES RECOVERED DURING DEEP SEA DRILLING PROJECT LEG 641
}

\author{
Daniel J. Fornari, Department of Geological Sciences, State University of New York at Albany, Albany, New York \\ Andrew D. Saunders, Department of Geology, Bedford College, Regent's Park, London, NW1 4NS, United Kingdom \\ and \\ Michael R. Perfit, Research School of Earth Sciences, Australian National University, Canberra, P.O. Box 4, Australia
}

\begin{abstract}
Fourteen microprobe analyses of basaltic glasses from three drill sites plus two dredged samples from the seafloor at the mouth of the Gulf of California suggest that magmatic liquids that cooled to form the volcanic crust in the Gulf of California have been fractionated, whereas other, more primitive submarine basalts from the Mid-Oceanic Ridge (MOR) have not. The limited chemical diversity among drill sites suggests that magmatic liquids, which erupted along the accretionary boundary in the Gulf of California, are grossly similar. Major-element variations in the glasses from Hole 474A may, in part, however, be attributed to simple crystal-liquid fractionation in a subridge magma chamber. Additionally, the analysis of a glass from Hole 475B, near the eastern continental slope of southernmost Baja California, suggests that magmatic liquids which produced submarine basalts associated with initial opening of the Gulf may have been chemically less evolved than present ones. Trace-element concentrations (Saunders et al., this volume, Pt. 2 [hereafter "this volume"]) in whole rocks from Hole 475B suggest that this magma may have experienced minor sialic contamination on its ascent through lower crustal continental material. Whole-rock and glass major-element concentrations, however, suggest that early Pliocene(?) basalts that erupted in Hole 475B were derived from a magmatic liquid of (deep) mantle origin. The liquid quickly rose to the surface with little shallow-level fractionation.
\end{abstract}

\section{INTRODUCTION}

Fresh basaltic glass from selvages or crusts of extrusive submarine volcanics provides an indirect means of assessing the chemical characteristics of magmatic liquids that erupt along the accretionary axis of the MOR. Whole-rock compositions are the result of interacting magmatic and secondary processes, and they reflect some stage of a crystallization sequence. They are often biased because of phenocryst concentrations and variable weathering effects; as such, they provide less quantitative information about the composition of the liquid from which they crystallized.

The quantity of data on basaltic seafloor glasses has increased steadily over the last five years, and numerous investigators have compiled major-element chemical characteristics of drilled, dredged, and submersible basalts from the major ocean basins and along the MOR (Melson et al., 1976; Bryan, 1979; Bence et al., 1979; Byerly and Sinton, 1980).

In this chapter we present 12 major-element analyses of basaltic glasses from 4 holes drilled by Glomar Challenger during Leg 64. Eight of the glasses were sampled from a typical oceanic, upper-crustal sequence of extrusive basalts from Hole 474A. Most of the glass recovered during Leg 64 occurs in this sequence; however, small amounts of glass were also recovered in the Guaymas Basin sites and are represented in this study by three samples from Holes 477 and $477 \mathrm{~A}$. The glass sample from Hole 475B, at the base of the continental slope and off the southeastern tip of Baja California, was taken from

\footnotetext{
${ }^{1}$ Curray, J. R., Moore, D. G., et al., Init. Repts. DSDP, 64: Washington (U.S. Govt. Printing Office).
}

a weathered cobble of olivine basalt that had retained some glass selvages. Additionally, glasses from two samples dredged near the mouth of the Gulf are included in these data. One sample is from the Alarcon Seamount $\left(23^{\circ} 16^{\prime} \mathrm{N} ; 108^{\circ} 42^{\prime} \mathrm{W}\right)$, and the other is from a basement outcrop in the Rise-Mazatlán Basin $\left(22^{\circ} 42^{\prime} \mathrm{N}\right.$, $\left.108^{\circ} 14.5^{\prime} \mathrm{W}\right)$.

\section{METHOD}

All glasses were analyzed at the Lamont-Doherty Geological Observatory on an ARL-EXM three-spectrometer electron microprobe. Glass fragments were mounted in epoxy resin, polished, and analyzed with a defocused electron beam ( $\sim 15 \mu \mathrm{m}$ spot size). The accelerating voltage was $20 \mathrm{kv}$, and the specimen current was approximately $0.3 \mu \mathrm{A}$ for $60 \mathrm{~s}$. Table 1 presents the averages computed from 10 analyses of each glass fragment (samples with Plot Numbers 13 and 14 average eight points). ${ }^{2}$ Synthetic and natural mineral standards and wholerock (artificial) and natural basaltic glasses ensured standardization. A more detailed description of the standardization procedures and data precision is reported in Fornari et al. (1979).

\section{RESULTS}

Figure 1 depicts the data from Table 1 on $\mathrm{MgO}$-variation diagrams; decreasing $\mathrm{MgO}$ appears to the right of each plot. To discuss the chemical characteristics of glasses from an individual site and to compare intersite glass compositions, we will discuss each oxide separately.

\section{$\mathrm{SiO}_{2}$}

The silica content of the glasses varies between 48 and $50.5 \mathrm{wt} . \%$, and only a vague pattern of increasing silica with decreasing $\mathrm{MgO}$ emerges. Several grouping and trends, however, do occur, and they become more ob-

\footnotetext{
${ }^{2}$ We will refer to the samples by their plot numbers, which appear on Table 1 above the official DSDP sample numbers.
} 
Table 1. Microprobe analyses of natural glasses, Leg 64 .

\begin{tabular}{|c|c|c|c|c|c|c|c|c|c|c|c|c|c|c|}
\hline Plot Number & 1 & 2 & 3 & 4 & 5 & 6 & 7 & 8 & 9 & 10 & 11 & 12 & 13 & 14 \\
\hline $\begin{array}{l}\text { DSDP } \\
\text { Sample } \\
\text { Number }\end{array}$ & $\begin{array}{c}474 \mathrm{~A}- \\
44-2, \\
34-38 \mathrm{~cm}\end{array}$ & $\begin{array}{c}474 \mathrm{~A}- \\
46-2 \\
112 \mathrm{~cm}\end{array}$ & $\begin{array}{l}474 \mathrm{~A}- \\
48-1, \\
138 \mathrm{~cm}\end{array}$ & $\begin{array}{l}474 \mathrm{~A}- \\
48-2 \\
93 \mathrm{~cm}\end{array}$ & $\begin{array}{c}474 \mathrm{~A}- \\
48-3 \\
1-2 \mathrm{~cm}\end{array}$ & $\begin{array}{l}474 \mathrm{~A}- \\
48-4 \\
82 \mathrm{~cm}\end{array}$ & $\begin{array}{c}474 \mathrm{~A}- \\
49-1 \\
2-3 \mathrm{~cm}\end{array}$ & $\begin{array}{c}474 \mathrm{~A}- \\
49-2 \\
31-35 \mathrm{~cm}\end{array}$ & $\begin{array}{c}475 \mathrm{~B}- \\
2-1 \\
32-40 \mathrm{~cm}\end{array}$ & $\begin{array}{c}477- \\
7-2 \\
4-6 \mathrm{~cm}\end{array}$ & $\begin{array}{c}477 \mathrm{~A}- \\
1-1 \\
0-3 \mathrm{~cm}\end{array}$ & $\begin{array}{c}477 \mathrm{~A}- \\
2-1 \\
13-14 \mathrm{~cm}\end{array}$ & $\begin{array}{l}\text { Alarcon } \\
\text { Seamount } \\
\text { Station } 94\end{array}$ & $\begin{array}{l}\text { Rise-Mazatlán } \\
\text { Basin } \\
\text { Station } 59\end{array}$ \\
\hline $\begin{array}{l}\text { Number of } \\
\text { Analyses }\end{array}$ & 10 & 10 & 10 & 10 & 10 & 10 & 10 & 10 & 10 & 10 & 10 & 10 & 8 & 8 \\
\hline $\mathrm{SiO}_{2}$ & 50.70 & 49.06 & 49.07 & 50.42 & 49.89 & 49.38 & 50.27 & 49.68 & 48.06 & 50.29 & 50.21 & 49.76 & 49.72 & 49.21 \\
\hline $\mathrm{Al}_{2} \mathrm{O}_{3}$ & 14.89 & 16.62 & 16.13 & 14.90 & 15.40 & 15.61 & 16.10 & 14.94 & 18.01 & 15.45 & 14.98 & 15.24 & 15.74 & 15.40 \\
\hline $\mathrm{TiO}_{2}$ & 1.73 & 1.70 & 2.15 & 1.71 & 1.73 & 2.13 & 2.15 & 2.35 & 1.47 & 2.00 & 1.95 & 1.98 & 1.33 & 1.42 \\
\hline $\mathrm{Fe}_{2} \mathrm{O}_{3} *$ & 1.04 & 1.02 & 1.06 & 1.00 & 1.04 & 1.13 & 1.06 & 1.18 & 0.93 & 1.02 & 1.00 & 1.03 & 0.95 & 1.06 \\
\hline $\mathrm{FeO}^{*}$ & 9.31 & 9.20 & 9.52 & 9.02 & 9.36 & 10.15 & 9.52 & 10.62 & 8.38 & 9.19 & 9.05 & 9.29 & 8.59 & 9.58 \\
\hline $\mathrm{MnO}$ & 0.18 & 0.20 & 0.14 & 0.16 & 0.17 & 0.19 & 0.20 & 0.16 & 0.17 & 0.18 & 0.18 & 0.17 & 0.16 & 0.19 \\
\hline $\mathrm{MgO}$ & 7.45 & 7.86 & 7.56 & 7.42 & 7.56 & 7.16 & 6.60 & 6.85 & 8.40 & 7.01 & 7.14 & 7.14 & 8.42 & 8.43 \\
\hline $\mathrm{CaO}$ & 11.24 & 11.21 & 11.24 & 11.61 & 11.64 & 10.91 & 10.25 & 10.90 & 11.36 & 10.96 & 11.16 & 11.26 & 11.71 & 11.72 \\
\hline $\mathrm{Na}_{2} \mathrm{O}$ & 2.78 & 2.63 & 2.83 & 2.67 & 2.70 & 2.88 & 2.88 & 2.67 & 3.00 & 2.95 & 3.01 & 2.51 & 3.00 & 2.48 \\
\hline $\mathrm{K}_{2} \mathrm{O}$ & 0.18 & 0.23 & 0.22 & 0.20 & 0.20 & 0.26 & 0.25 & 0.32 & 0.14 & 0.24 & 0.26 & 0.47 & 0.14 & 0.14 \\
\hline $\mathrm{P}_{2} \mathrm{O}_{5}$ & 0.12 & 0.11 & 0.13 & 0.10 & 0.09 & 0.19 & 0.14 & 0.22 & 0.07 & 0.19 & 0.09 & 0.17 & 0.11 & 0.09 \\
\hline $\mathrm{Cr}_{2} \mathrm{O}_{3}$ & 0.04 & 0.05 & 0.0 & 0.04 & 0.04 & 0.02 & 0.04 & 0.01 & 0.03 & 0.02 & 0.04 & 0.03 & 0.03 & 0.05 \\
\hline Total & 99.66 & 99.89 & 99.82 & 99.25 & 99.82 & 100.00 & 99.42 & 99.94 & 100.02 & 99.50 & 99.07 & 99.05 & 99.90 & 99.77 \\
\hline $\mathrm{Mg}$ Number & 58.8 & 60.4 & 58.6 & 59.5 & 59.0 & 55.7 & 55.3 & 53.5 & 64.1 & 57.6 & 58.5 & 57.8 & 63.6 & 61.1 \\
\hline $\mathrm{CaO} / \mathrm{Al}_{2} \mathrm{O}_{3}$ & 0.755 & 0.674 & 0.697 & 0.779 & 0.756 & 0.699 & 0.637 & 0.730 & 0.631 & 0.709 & 0.745 & 0.739 & 0.744 & 0.761 \\
\hline \multicolumn{15}{|l|}{ CIPW Norms } \\
\hline OR & 1.06 & 1.36 & 1.30 & 1.18 & 1.18 & 1.54 & 1.48 & 1.89 & 0.83 & 1.42 & 1.54 & 2.78 & 0.83 & 0.83 \\
\hline $\mathrm{AB}$ & 23.52 & 22.26 & 23.95 & 22.59 & 22.85 & 24.37 & 24.37 & 22.59 & 23.28 & 24.96 & 25.47 & 21.24 & 25.39 & 20.99 \\
\hline AN & 27.63 & 32.87 & 30.67 & 28.09 & 29.32 & 28.91 & 30.27 & 27.84 & 35.27 & 28.22 & 26.60 & 28.94 & 29.08 & 30.48 \\
\hline $\mathrm{NE}$ & - & - & - & - & - & - & - & - & 1.14 & - & - & - & - & - \\
\hline DI & 22.48 & 18.07 & 19.93 & 23.67 & 22.86 & 19.81 & 16.24 & 20.55 & 16.83 & 20.53 & 23.12 & 21.25 & 23.13 & 22.20 \\
\hline Wo & 11.46 & 9.23 & 10.16 & 12.08 & 11.65 & 10.07 & 8.25 & 10.42 & 8.64 & 10.46 & 11.79 & 10.83 & 11.85 & 11.33 \\
\hline En & 6.34 & 5.22 & 5.65 & 6.77 & 6.47 & 5.37 & 4.40 & 5.40 & 5.13 & 5.76 & 6.57 & 5.98 & 6.95 & 6.39 \\
\hline Fs & 4.68 & 3.62 & 4.12 & 4.82 & 4.74 & 4.37 & 3.59 & 4.73 & 3.06 & 4.31 & 4.76 & 4.45 & 4.33 & 4.48 \\
\hline HY & 16.18 & 9.53 & 6.99 & 15.17 & 10.95 & 10.07 & 19.14 & 16.20 & - & 13.82 & 10.44 & 15.35 & 2.68 & 9.87 \\
\hline En & 9.31 & 5.63 & 4.04 & 8.85 & 6.33 & 5.55 & 10.54 & 8.64 & - & 7.91 & 6.06 & 8.80 & 1.65 & 5.81 \\
\hline Fs & 6.87 & 3.90 & 2.95 & 6.32 & 4.62 & 4.52 & 8.60 & 7.56 & - & 5.91 & 4.38 & 6.55 & 1.03 & 4.06 \\
\hline $\mathrm{OL}$ & 3.68 & 10.79 & 11.53 & 3.58 & 7.62 & 9.19 & 1.98 & 4.15 & 18.34 & 4.84 & 6.49 & 3.83 & 14.62 & 10.91 \\
\hline Fo & 2.03 & 6.12 & 6.40 & 2.00 & 4.22 & 4.84 & 1.04 & 2.11 & 11.06 & 2.65 & 3.61 & 2.10 & 8.67 & 6.16 \\
\hline $\mathrm{Fa}$ & 1.65 & 4.67 & 5.13 & 1.58 & 3.40 & 4.35 & 0.94 & 2.04 & 7.28 & 2.19 & 2.88 & 1.73 & 5.95 & 4.75 \\
\hline MG & 1.51 & 1.48 & 1.54 & 1.45 & 1.51 & 1.64 & 1.54 & 1.71 & 1.35 & 1.48 & 1.45 & 1.49 & 1.38 & 1.54 \\
\hline IL & 3.29 & 3.23 & 3.65 & 3.25 & 3.29 & 4.05 & 4.08 & 4.46 & 2.79 & 3.80 & 3.70 & 3.76 & 2.53 & 2.70 \\
\hline AP & 0.26 & 0.24 & 0.28 & 0.22 & 0.20 & 0.41 & 0.31 & 0.48 & 0.15 & 0.41 & 0.20 & 0.37 & 0.24 & 0.20 \\
\hline CR & 0.06 & 0.07 & - & 0.06 & 0.06 & 0.03 & 0.06 & 0.01 & 0.04 & 0.03 & 0.06 & 0.04 & 0.04 & 0.07 \\
\hline
\end{tabular}

Note: Analytical method yielded total iron as $\mathrm{FeO} ; \mathrm{FeO}^{*}=0.85 \times \mathrm{FeO}^{*} \mathrm{Fe}_{2} \mathrm{O}_{3}{ }^{*}=\mathrm{FeO} \times 0.166695 ; \mathrm{Fe}^{2+}$ used in $\mathrm{Mg}$ number calculation $=0.9 \mathrm{FeO}$; norm calculations were done using $\mathrm{FeO}^{2+}=0.85 \mathrm{FeO}$.

vious and distinct in the other oxide plots. Samples 1 through 8 (Hole 474A) and 10, 11, and 12 (Holes 477, 477A) fall between 49 and 50.5 wt. \%; they are clearly distinct from Sample 9 (Hole 475B), which has the lowest $\mathrm{SiO}_{2}$ content ( $48 \mathrm{wt} . \%$ ) of all samples and has major-element characteristics similar to Samples 13 and 14.

\section{$\mathrm{Al}_{2} \mathrm{O}_{3}$}

All of the glasses except Sample 9 have $\mathrm{Al}_{2} \mathrm{O}_{3}$ contents that range from 15 to $16.6 \mathrm{wt} . \%$ and are within the field determined by Bence et al. (1979) for ocean-ridge basaltic glasses (see Perfit et al., this volume, Pt. 2 [hereafter "this volume"]). The trend among the glasses of decreasing $\mathrm{Al}_{2} \mathrm{O}_{3}$ with $\mathrm{MgO}$ suggests plagioclase- and olivine-controlled fractionation. Sample 9 has the highest content of $\mathrm{Al}_{2} \mathrm{O}_{3}(18 \mathrm{wt} . \%$ ), which is $1.6 \mathrm{wt} . \%$ higher than that found in the correlative whole-rock analysis reported by Saunders et al. (this volume) for a sample taken at $2 \mathrm{~cm}$ from Section 1 of Core 2, Hole 475B.

\section{$\mathrm{FeO}^{*}$}

Total $\mathrm{FeO}$ contents exhibit a negative correlation with $\mathrm{MgO}$ and range from 9.2 to $11.7 \mathrm{wt} \%$. Note that the $\mathrm{Fe}_{2} \mathrm{O}_{3}$ used in calculating CIPW norms was calculated from microprobe analyses, which yielded total iron as $\mathrm{FeO}$ (see Table 1, note). Even though glasses in Samples 2 through 8 came from one petrographically distinct unit (Unit 7 of Saunders et al., this volume), a significant degree of fractionation from Samples 1 through 5 to Samples 6 through 8 is apparent. The trend of iron enrichment with differentiation, however, appears to be greater in Samples 2, 3, 6, and 8 than in 1, 4, 5, and 7 . The latter group are more like Samples 10 through 12, which also show relatively low FeO* contents (10.0-10.3 wt.\%). Although similar in other respects, Samples 13 and 14 have significantly different $\mathrm{FeO}^{*}$ contents $(\sim 1$ wt. $\%$ difference). Sample 9 is again separated from the other glasses, because it has the lowest $\mathrm{FeO}^{*}$ content (9.3 wt. \%) - a consequence of its relatively less-fractionated nature $(\mathrm{Mg}$ number $=64.1)$.

\section{MgO-Mg Number}

Compared to the basalts recovered during Leg 64 (see Saunders et al., this volume; Perfit et al., this volume), the glasses have a much more restricted range of $\mathrm{MgO}$ and $\mathrm{Mg}$ number. The average $\mathrm{Mg}$ number $(58.8 \pm 2.9)$ for the 14 glasses reported here is nearly identical to the average of 600 basalt glasses from the ocean floor (58.6; Wilkinson, in press). Based on their calculated Mg numbers and $\mathrm{MgO}$ contents ( $~ 8.4$ wt. \%) Samples 9,13 , and 14 are the most primitive glasses yet recovered from the Gulf of California. Sample 2, containing 7.86 wt.\% $\mathrm{MgO}$, is the most primitive glass from Hole 474A. It may represent an analogous, parental liquid composi- 
tion from which the more evolved glasses (Samples 7 and 8 ) in the hole were derived. As with Sample 6 from Hole 474A, Samples 10 through 12 from Hole 477 are moderately evolved $(\mathrm{Mg}$ numbers $=57.6-58.5)$ and appear to be transitional liquid compositions between the most primitive and more fractionated glasses with the lowest $\mathrm{MgO}$ contents (6.6-6.8 wt. \%).

\section{$\mathrm{TiO}_{2}$}

There is a broad linear trend of increasing $\mathrm{TiO}_{2}$ with decreasing $\mathrm{MgO}$ in the glasses (Fig. 1). Basalt glasses from the MOR characteristically exhibit this trend as a consequence of crystal fractionation (Fig. 2; Perfit, this volume). The most primitive glasses $(9,13,14)$ have the lowest $\mathrm{TiO}_{2}$ contents (1.33-1.47 wt.\%), whereas the more evolved samples are slightly more variable, having a range from 1.70 to $2.35 \mathrm{wt} . \% \mathrm{TiO}_{2}$.

The divergent trends of increasing $\mathrm{FeO}^{*}$ in Hole 474A glasses are also apparent in the $\mathrm{TiO}_{2}$ variations. Samples 2, 3, 6, and 8 exhibit a larger degree of $\mathrm{TiO}_{2}$ enrichment than Samples 1, 4, 5, and 7. Furthermore, Samples 11 and 12 have, as do the $\mathrm{FeO}^{*}$ contents, more affinities with the latter group.

\section{$\mathrm{CaO}-\mathrm{CaO} / \mathrm{Al}_{2} \mathrm{O}_{3}$}

In general, the glass data exhibit a linear decrease of $\mathrm{CaO}$ with decreasing $\mathrm{MgO}$ (Fig. 1). Although Samples 13 and 14 have the highest $\mathrm{CaO}$ contents, Sample 9 has a somewhat low content (11.36 wt.\%) in comparison to the moderately fractionated basalts (11.6-10.9 wt.\%). In detail, Samples $1,4,5$, and 7 show a more rapid decrease in $\mathrm{CaO}$ with $\mathrm{MgO}$ than Samples 2, 3, 6, and 8, which exhibit little variation.

Because of decreasing $\mathrm{Al}_{2} \mathrm{O}_{3}$ contents with $\mathrm{MgO}$ in the latter group, these four samples increase linearly in $\mathrm{CaO} / \mathrm{Al}_{2} \mathrm{O}_{3}$ ratios with decreasing $\mathrm{Mg}$ number, this parallels the trend of the crystalline basalts in Hole 474A (see Perfit et al., this volume) and MOR basalt glasses in general. Compared to the other Leg 64 glasses and crystalline basalts, Samples 1, 4, and 5 have relatively high $\mathrm{CaO} / \mathrm{Al}_{2} \mathrm{O}_{3}$ ratios. Assuming they are related to Sample 7 , as already mentioned, they exhibit a sharp decrease in $\mathrm{CaO} / \mathrm{Al}_{2} \mathrm{O}_{3}$ ratio with decreasing $\mathrm{Mg}$ number. Sample 9 is again somewhat unusual in having the lowest $\mathrm{CaO}$ / $\mathrm{Al}_{2} \mathrm{O}_{3}$ ratio. Samples 10 through 12 have $\mathrm{CaO} / \mathrm{Al}_{2} \mathrm{O}_{3}$ ratios similar to many of the more evolved Leg 64 basalts (see Perfit et al., this volume; Saunders et al., this volume).

\section{$\mathrm{Na}_{2} \mathrm{O} / \mathrm{K}_{2} \mathrm{O} / \mathbf{P}_{2} \mathrm{O}_{5}$}

The alkali and $\mathrm{P}_{2} \mathrm{O}_{5}$ abundances (Fig. 1) indicate very little distinction among the groups of glasses. All three plots show flat-to-slightly increasing trends and fractionation for these three oxides. Alkali contents of the glasses are near the upper range of most oceanic-ridge basaltic glasses (Bence et al., 1979).

\section{DISCUSSION}

The chemical characteristics of the Leg 64 glasses are generally similar as a group, but contrast to those of the glasses from other segments of the MOR. In particular, unlike more primitive (higher-Mg number) MOR glasses and basalts from Leg 64, they appear to have undergone a reasonable degree of fractional crystallization. On average, their $\mathrm{Mg}$ numbers are lower than those of the crystalline basalts from the same holes. In part, this may be caused by some accumulation of ferromagnesian phases in the crystalline basalts. That the glasses from each hole represent some of the most evolved samples, however, suggests that they are products of crystal-liquid fractional crystallization, rather than direct partial melts from the mantle.

The Leg 64 glasses plot in a field parallel to, but distant from, FAMOUS glasses on a CIPW normative triangle (Fig. 2). The Leg 64 glasses fall in nearly the same field as glasses from the Cayman Trough (Thompson et al., 1980), which have probably undergone simple, single-stage fractionation from an evolved ocean-ridge parental magma. The Leg 64 and the Cayman glasses are higher in $\mathrm{Na}_{2} \mathrm{O}$ than FAMOUS glasses; this partially accounts for their being further into the plagioclase field than the FAMOUS glasses. Figure 3 is a plot of $\mathrm{FeO}^{*}$ / $\mathrm{MgO}$ versus $\mathrm{TiO}_{2}$ and shows the Leg 64 data falling in a field separate from Mid-Atlantic Ridge (MAR) glasses and similar to Cayman glasses and East Pacific Rise (Batiza et al., 1977) and Isla Tortuga tholeiites (Batiza, 1977). Leg-64 glasses are higher in $\mathrm{TiO}_{2}$ for a given $\mathrm{FeO}^{*} / \mathrm{MgO}$ ratio than the MAR glasses. This feature is apparent in the crystalline basalts as well (Perfit et al., this volume).

The major-element characteristics of the Leg 64 glasses, as presented in Figure 1, suggest that there were temporal variations in the Hole $474 \mathrm{~A}$ magmatic liquids. One example of this is the chemical difference between Samples $2,3,6$, and 8 and $1,4,5$, and 7 . The differences may be a consequence of different liquid lines of descent from a single, primitive, parental magma or of derivations from two or three different parental magmas. Perfit et al. (this volume) have shown that basalts from Units 6,7 , and 8 in Hole $474 \mathrm{~A}$ can be related by the fractional crystallization of $\mathrm{Plag}+\mathrm{Ol} \pm \mathrm{Cpx}$ from the same or similar parental magmas; but different liquid lines of descent may be involved. For instance, assuming that Sample 2 represents the least-fractionated liquid, then the evolved glass of Sample 7 could be derived from Plag $+\mathrm{Ol}+\mathrm{Cpx}$ fractionation in the wt.\% ratio $2: 1: 1$ whereas Sample 8 requires only Plag $+\mathrm{Ol}(3: 1)$ fractionation (Perfit et al., this volume). The rapid fall in $\mathrm{CaO}$ and only gradual increases in $\mathrm{FeO}^{*}$ and $\mathrm{TiO}_{2}$ with decreasing $\mathrm{MgO}$ in Samples 1, 4, 5, and 7 (Fig. 1) may be a result of significant $\mathrm{Cpx}$ fractionation-unlike the fractionation controlled solely by $\mathrm{Ol}+\mathrm{Plag}$ in the other glasses.

The differences in fractionating assemblages may be caused by temporal variations in the depth of magma crystallization, changes in phase stabilities as liquids evolve, or mixing of primitive magmas with more evolved types. Clearly, the major element variations in basalts from Hole 474A suggest a multistage evolution.

Chemical data strongly suggest that the basalts from Holes 477 and 477A could have been derived from a common parental magma by varying degrees of $\mathrm{Ol}+$ Plag fractionation (Saunders et al., this volume). The high $\mathrm{CaO} / \mathrm{Al}_{2} \mathrm{O}_{3}$ ratios (Table 1) and relatively low $\mathrm{Mg}$ 
D. J. FORNARI, A. D. SAUNDERS, M. R. PERFIT

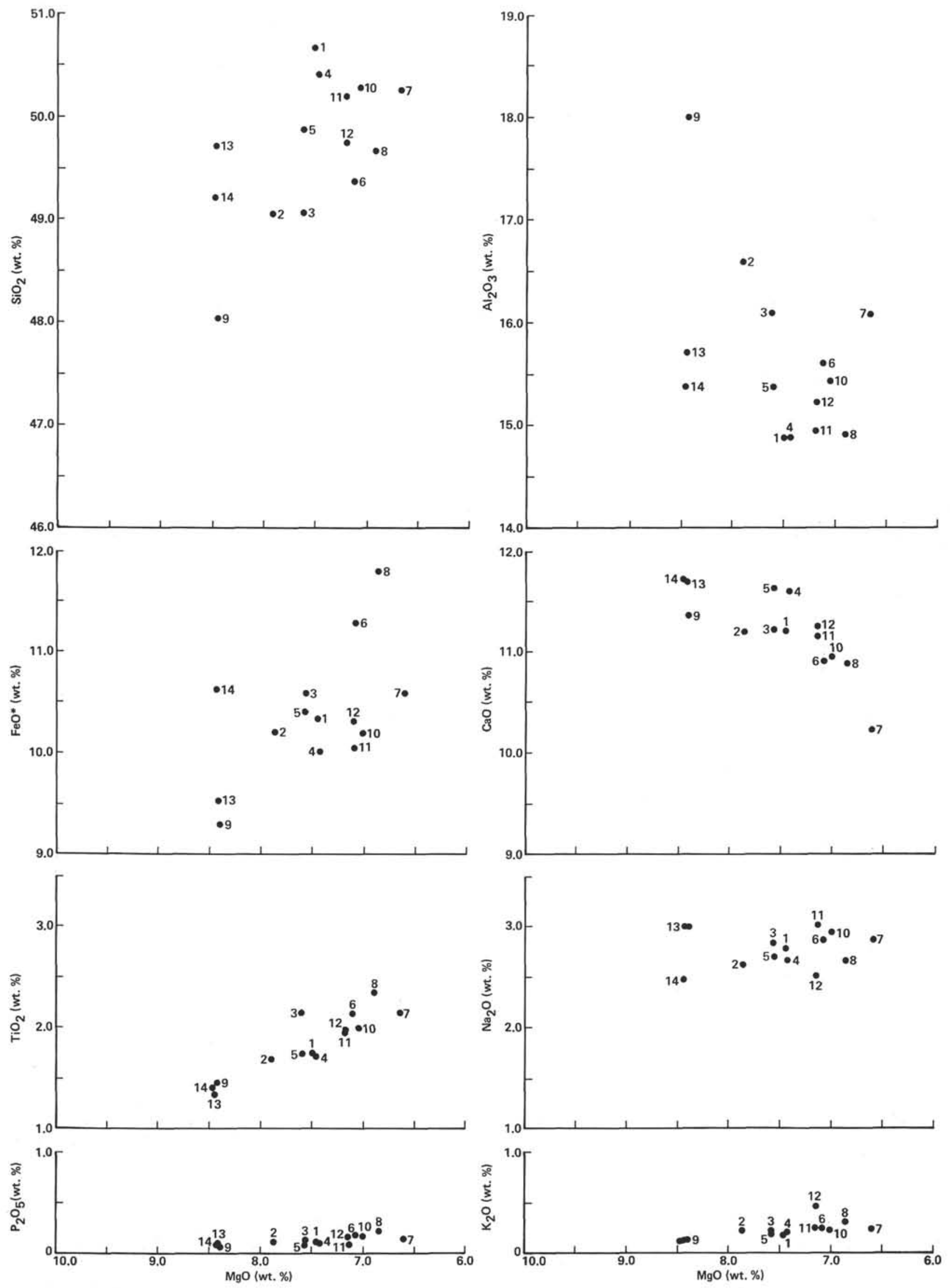

Figure 1. $\mathrm{MgO}$ variation diagrams, Leg 64 glasses. 


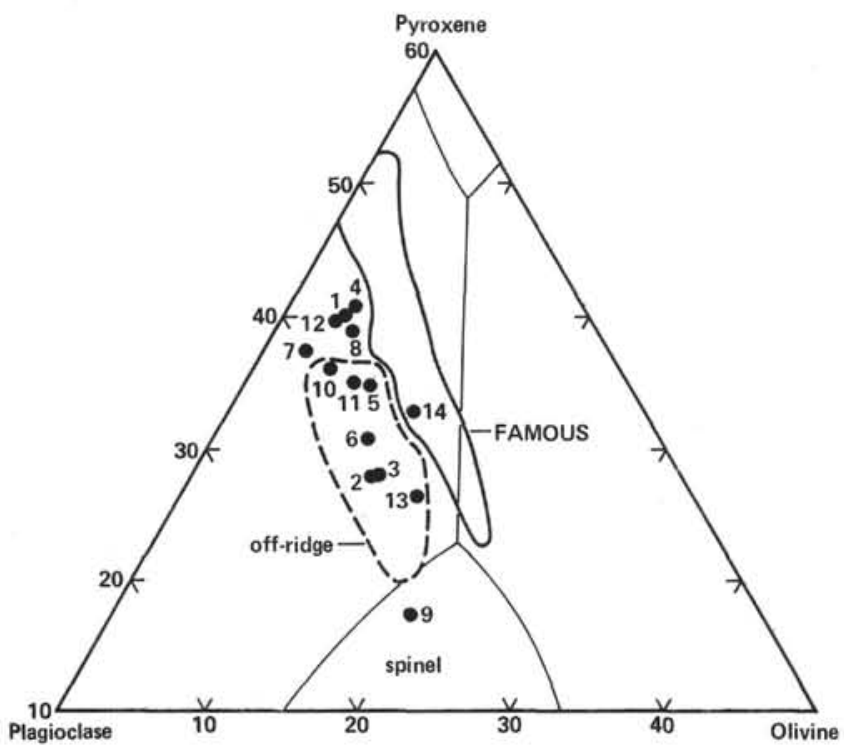

Figure 2. CIPW normative triangle (plagioclase-pyroxene-olivine), Leg 64 glass data. (Fields for FAMOUS and off-ridge glass data are from various sources in Bryan [1979] and Thompson et al. [1980]. Plagioclase is total An + Ab, pyroxene is total Di + En + Fs, and olivine is total Fo $+\mathrm{Fa}$. Phase boundaries are after Osborn and Tait [1952].)

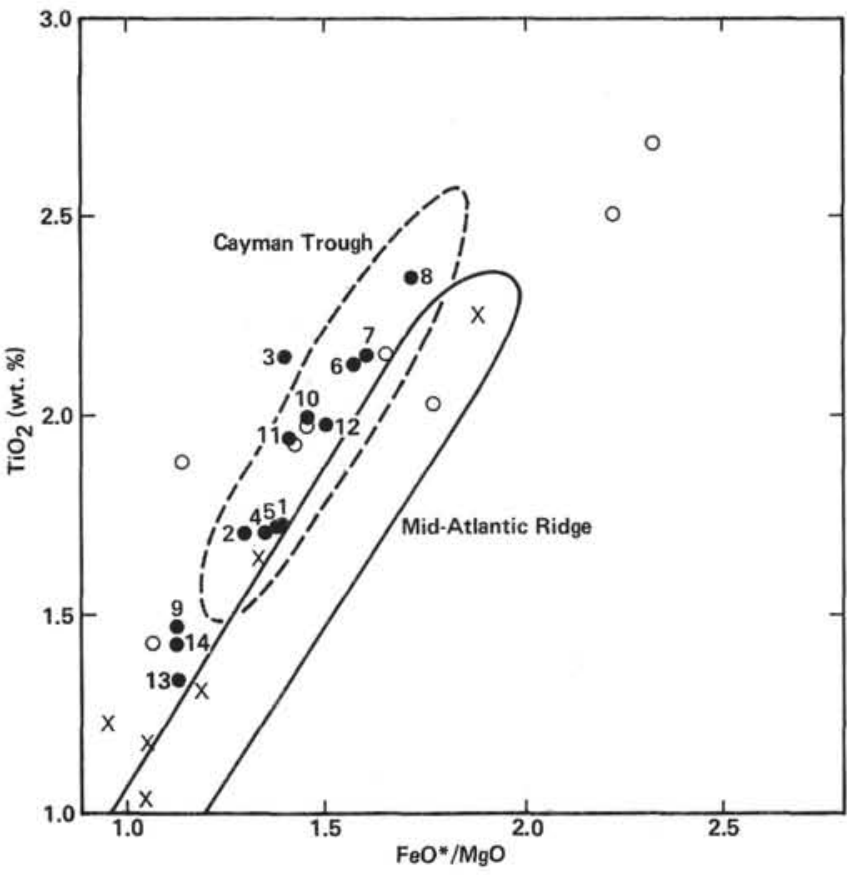

Figure 3. $\mathrm{TiO}_{2}-\mathrm{FeO} * / \mathrm{MgO}$ variation diagram, Leg 64 glasses. (Solid circles $=$ Leg 64 sample numbers; open circles $=$ basaltic lavas from Isla Tortuga-a young [1.7 Ma] tholeiitic volcanic island in the central Gulf of California [Batiza, 1978]; crosses = oceanfloor basalts dredged from the East Pacific Rise, near the Siqueiros Transform [Batiza et al., 1977]. Cayman Trough and MidAtlantic Ridge glass fields are from Thompson et al. [1980].)

numbers of Samples 10-12 support this proposal, but small amounts of $\mathrm{Cpx}$ fractionation may also have been important in generating intermediate liquids from primitive parents (Perfit et al., this volume).
Sample 9 from Hole 475B exhibits major element characteristics that differ from the other Leg 64 samples. On geographic evidence alone it may represent basaltic magma that accompanied the beginning of oceanic crustal formation in the Gulf of California. For it to have been derived from a more primitive magma (i.e., similar in composition to the accompanying olivine basalt), equal amounts of Plag, $\mathrm{Ol}$, and $\mathrm{Cpx}$ would have to be subtracted (Perfit et al., this volume). This agrees neither with the liquidus phases nor with the trace-element variations (Saunders et al., this volume). Alternatively, it may have experienced minor, lower-crustal contamination from relict continental material and may have originated from a deep asthenospheric source, rapidly rising to the surface with little shallow-level fractionation. It does reflect a more primitive basaltic liquid and, with Samples 13 and 14, one could suggest that their average major-element content is a valid estimate for juvenile, accretionary magmatic liquids that erupted in the newly formed Gulf of California.

\section{SUMMARY}

Microprobe analyses of basaltic glasses from Leg 64 indicate that major-element characteristics of magmatic liquids that erupted along the accretionary boundary in the Gulf of California are grossly similar. The majorelement variations that do occur, as exemplified by the glasses from Hole 474A, may, in part, be explained by simple crystal-liquid fractionation as magma batches evolve within the magma chamber or during their ascent to the seafloor. Different sources and magma mixing, however, cannot be ruled out on major-element evidence alone. Samples 9,13, and 14 are less-fractionated samples and are likely to represent older types of magmatic liquids that erupted on the newly formed oceanic crust of the Gulf of California.

\section{ACKNOWLEDGMENTS}

Jeff Niemitz kindly supplied the glasses from Alarcon Seamount (13) and the Mazatlán-Rise Basin (14). Donna Kelly, Heather Sloan, Maureen Martuscello, and Debbie Schwartz assisted in typing and preparing tables and figures; their help is greatly appreciated. Don Elthon assisted the senior author with the microprobe analyses and provided moral and technical support in the face of instrument intransigence.

\section{REFERENCES}

Batiza, R., 1978. Geology, petrology and geochemistry of Isla Tortuga, a recently formed tholeiitic island in the Gulf of California. Geol. Soc. Am. Bull., 89:1309-1324.

Batiza, R., Rosendahl, B. R., and Fisher, R. L., 1977. Evolution of oceanic crust 3. Petrology and chemistry of basalts from the East Pacific Rise and the Siqueiros Transform Fault. J. Geophys. Res., $82: 265-276$

Bence, A. E., Baylis, D. M., Bender, J. F., et al., 1979. Controls on the major and minor element chemistry of mid-ocean ridge basalts and glasses. In Talwani, M., Harrison, C. G., and Hayes, D. E., (Eds.), Deep Drilling Results in the Atlantic Ocean: Ocean Crust: Washington (American Geophysical Union), pp. 331-341.

Bryan, W. B., 1979. Regional variation and petrogenesis of basalt glasses from the FAMOUS area, Mid-Atlantic Ridge. J. Petrol. 20(Pt. 2):293-325.

Byerly, G. R., and Sinton, J. M., 1980. Compositional trends in natural basaltic glasses from Deep Sea Drilling Project Holes 417D and 418A. In Donnelly, T., Francheteau, J., Bryan, W., Robinson, P., 
Flower, M., Salisbury, M., et al., Init. Repts. DSDP, 51, 52, 53, Pt. 2: Washington (U.S. Govt. Printing Office), 957-971.

Fornari, D. J., Peterson, D. W., Lockwood, J. P., et al., 1979. Submarine extension of the southwest rift zone of Mauna Loa Volcano, Hawaii: Visual observations from U.S. Navy Deep Submergence Vehicle DSV Sea Cliff. Geol. Soc. Am. Bull., 90:435-443.

Melson, W. G., Vallier, T. L., Wright, J. L., et al., 1976. Chemical diversity of abyssal volcanic glass erupted along Pacific, Atlantic and Indian Ocean floor spreading centers. Geophysics of Pacific
Ocean Basin and Its Margins: Geophysical Monograph 19: Washington (American Geophysical Union), 351-363.

Osborn, E. F., and Tait, D. B., 1952. The system diopside-forsteriteanorthosite. Am. J. Sci., Bowen Volume, 413-433.

Thompson, G., Bryan, W. B., and Melson, W. G., 1980. Geological and geophysical investigation of the Mid-Cayman Rise Spreading Center: Geochemical variation and petrogenesis of basalt glasses. J. Geol., 88:41-55.

Wilkinson, J. F. G., in press. The genesis of mid-ocean ridge basalt. Earth Sci. Rev. 